\title{
LEGAL FLOWS: CONTRIBUTIONS OF EXILED LAWYERS TO THE CONCEPT OF "CRIMES AGAINST HUMANITY" DURING THE SECOND WORLD WAR
}

\author{
KERSTIN VON LINGEN \\ Cluster of Excellence - "Asia and Europe in a Global Context," Heidelberg University \\ E-mail: lingen@asia-europe.uni-heidelberg.de
}

\begin{abstract}
This article addresses the normative framework of the concept of "crimes against humanity" from the perspective of intellectual history, by scrutinizing legal debates of marginalized (and exiled) academic-juridical actors within the United Nations War Crimes Commission (UNWCC). Decisive for its successful implementation were two factors: the growing scale of mass violence against civilians during the Second World War, and the strong support and advocacy of "peripheral actors," jurists forced into exile in London by the war. These jurists included representatives of smaller Allied countries from around the world, who used the commission's work to push for a codification of international law, which finally materialized during the London Conference of August 1945. This article studies the process of mediation and the emergence of legal concepts. It thereby introduces the concept of "legal flows" to highlight the different strands and older traditions of humanitarian law involved in coining new law. The experience of exile is shown to have had a significant constitutive function in the globalization of a concept (that of "crimes against humanity").
\end{abstract}

Crimes against civilians have always been perceived as the most heinous of crimes. During the 1940 s in London, exiled lawyers within the United Nations War Crimes Commission (UNWCC) were among the main protagonists to coin the concept of "crimes against humanity." Underlying this concept is the assumption that "citizens are under protection of international law even when they are victimized by their own compatriots." "The UNWCC was a hub of legal thought during the war, an epistemic community initially formed by European protagonists forced into exile by German occupation, along with Chinese representatives who likewise suffered under Japanese occupation. I will

Beth van Schaack, "The Definition of Crimes against Humanity: Resolving the Incoherence," Columbia Journal of Transnational Law 37 (1998-9), 787-850, at 791. 
argue that by using global intellectual history as a lens and by focusing on terms like "humanity" and "public conscience," we can demonstrate how an epistemic community materializes via its global approach-and on a definitively transnational scale - thereby leading to the coinage of new notions of justice as well as new forms of argumentation and new strategic goals. This analysis is drawn from the largely underexplored papers of the UNWCC and its predecessors. ${ }^{2}$

This article argues that without the engagement of exiled lawyers, mainly from marginalized states - smaller European states as well as China-there would never have emerged a self-consciously "global" project of penalizing war crimes on a planetary scale, linking contemporaneous realities with future horizons. "Global" is here understood not only in the context of the magnitude of the endeavor, but also as referring to the public space (to borrow Homi Bhabha's famous approach ${ }^{3}$ ) that was created between hitherto unconnected actors by the exile situation. An important path of inquiry refers thus to the boundaries of this public space, as well as to the argumentation and communication used. ${ }^{4}$

To assess the contribution of exiled lawyers in coining legal concepts, the approach of global intellectual history provides a fresh angle of analysis, as does the recent emphasis on internationalism. ${ }^{5}$ Taking a cue from Moyn's and Sartori's postulation about "recovering the topography of the network and tracing its construction, spread and functionaries," added to certain "knowledge brokers" and "intermediaries," "this article argues that exiled lawyers in London were at the heart of legalist endeavors of the time. They not only were united by profession, but also acted as something like diplomatic intermediaries, operating via the political platforms constituted by international organizations and related think tanks. ${ }^{7}$ As Akira Iriye has underlined, networks and international organizations, seen as "arenas of exchange," developed into an alternative tool

2 On the UNWCC, research has been intensified recently, but not using intellectual history as a lens; see Dan Plesch, Human Rights after Hitler: The lost History of Prosecuting Axis War Crimes (Washington, DC, 2017), who uses a political-science approach.

3 Homi Bhabha, The Location of Culture (London, 1984).

4 Martin Geyer and Johannes Paulmann, "Introduction: The Mechanics of Internationalism," in Martin H. Geyer and Johannes Paulmann, eds., The Mechanics of Internationalism: Culture, Society, and Politics from the 1840 s to the First World War (London, 2001), 1-25, at 11.

5 David Armitage, Foundations of Modern International Thought (Cambridge, 2012).

6 Samuel Moyn and Andrew Sartori, "Approaches to Global Intellectual History," in Moyn and Sartori, eds., Global Intellectual History (New York, 2013), 3-30, at 13.

7 Andrew Webster, "The Transnational Dream: Politicians, Diplomats and Soldiers in the League of Nations' Pursuit of International Disarmament, 1920-1938," Contemporary European History 14/4 (2005), 493-518; Helen McCarthy, "The Lifeblood of the League? Voluntary Associations and League of Nations Activism in Britain," in Daniel Laqua, ed., 
to exert influence. ${ }^{8}$ He proposes the term "cultural internationalism" to describe a phenomenon that links "countries and peoples through the exchange of ideas and persons, through scholarly cooperation, or through efforts facilitating cross-national understanding."9 As Jürgen Osterhammel has shown, in the nineteenth century, actors had already begun creating global spaces of debate, and law was an important field to engage with. ${ }^{10}$ While describing the first global network of internationalist lawyers which emerged in Ghent in 1873, Martti Koskenniemi has highlighted the significance of legal scholars under the term "the men of 1873." 11 The impact of their debates was significant. As Daniel Marc Segesser argues, members of legal associations-like the famous Institut de droit international in Ghent, the International Law Association and Association internationale de droit pénal—were as influential as the Human Rights Watch is today. ${ }^{12}$ To study the process of mediation and the emergence of legal concepts, this article therefore speaks of "legal flows," highlighting the various strands and traditions involved in coining new law.

To frame the notion of exiled lawyers, I have also taken a cue from the notion of "semi-peripheral states" following Arnulf Becker Lorca, understood as actors with no access to international or formal state power and thus no means to implement their innovations. Becker Lorca postulates that affiliation with a "semi-peripheral" state was decisive for scholars to advance new concepts, because they acted relatively freely of the restraints of realpolitik. ${ }^{13}$ Although the UNWCC emerged in a genuinely European setting-London as the hub of exiled communities, initially uniting only Europeans and later involving many extraEuropean members - the notion of sidelined actors is useful to interrogate the emergence of the concept of crimes against humanity. Although the disadvantages faced by the smaller states of Central and Eastern Europe as actors in international discourse were, of course, not comparable to those of colonial actors, an element

Internationalism Reconfigured: Transnational Ideas and Movements between the World Wars (London, 2011), 187-208.

8 Akira Iriye, Global Community: The Role of International Organizations in the Making of the Contemporary World (Berkeley, 2002).

$9 \quad$ Akira Iriye, Cultural Internationalism and World Order (Baltimore, 1997), 3.

10 Jürgen Osterhammel, Die Verwandlung der Welt: Eine Geschichte des 19. Jahrhunderts (Munich, 2011).

11 Martti Koskenniemi, The Gentle Civilizer of Nations: The Rise and Fall of International Law, 1870-1960 (Cambridge, 2002).

12 Daniel Marc Segesser, Recht statt Rache oder Rache durch Recht? Die Ahndung von Kriegsverbrechen in der internationalen fachwissenschaftlichen Debatte 1872-1945 (Paderborn, 2010), 71.

13 Arnulf Becker Lorca, Mestizo International Law: A Global Intellectual History 1842-1933 (Cambridge, 2014), 8 . 
of "secondness" was detectable and deeply rooted in Victorian perceptions of statehood, as was a noteworthy imbalance of access to power, expressed in the distinction of "greater" and "smaller" states. ${ }^{14}$ The notion of "peripheral impulses" is thus also applicable to European states if their access to power and resources was similarly limited, as Bardo Fassbender and Anne Peters have argued regarding legal strands. ${ }^{15}$ Peer Zumbansen has scrutinized the impact of legal actors in transnational discourses and advocated a closer analysis of legal source materials, memoranda, and biographical details. ${ }^{16}$

As Mark Mazower has pointed out, the interwar years and the advent of internationalism already revealed the importance of global encounter and arenas of debate, as evident in the League of Nations and the later United Nations. ${ }^{17}$ However, I argue here that older hierarchies and existing power structures persisted even in apparently supranational bodies, and continued to cause friction and frustration, especially with actors from smaller states. Glenda Sluga has highlighted, when observing the framework of international organizations, how they formed an arena of engagement especially for nations that were not yet sovereign or were newly so, or for minorities that were still sidelined. ${ }^{18}$ Following the dismantling of the Habsburg Empire within the Versailles negotiations of 1919 and Wilson's "Fourteen points," smaller states from Central Europe rose to the international stage. In the interwar years, actors like Poland and Czechoslovakia, but also Belgium and the Netherlands, were eager to make their voices heard in international bodies - even more so when in 1939 their statehood was threatened again by their German neighbors. Organizations like the later UNWCC could thus serve as what Madeleine Herren describes with regard to Swiss foreign policy endeavors as a "back door to power" for smaller states and during a period of exile. ${ }^{19}$ My point is that the exile situation offered a somewhat global intellectual

14 Georgios Varouxakis, “'Great' Versus 'Small' Nations: Size and National Greatness in Victorian Political Thought," in Duncan Bell, ed., Victorian Visions of Global Order: Empire and International Relations in Nineteenth-Century Political Thought (Cambridge, 2007), 136-58, at 136.

15 Bardo Fassbender and Anne Peters, "Introduction: Towards a Global History of International Law," in Bardo Fassbender, Anne Peters, and Simone Peter, eds., The Oxford Handbook of the History of International Law (Oxford, 2012), 1-25, at 9.

16 Peer Zumbansen, "Defining the Space of Transnational Law: Legal Theory, Global Governance and Legal Pluralism," in G. Handl, J. Zekoll, and P. Zumbansen, eds., Beyond Territoriality: Transnational Legal Authority in an Age of Globalization (Leiden, 2012), 305-35.

17 Mark Mazower, No Enchanted Place: The End of Empire and the Ideological Origins of the United Nations (Princeton, 2009).

18 Glenda Sluga, Internationalism in the Age of Nationalism (Philadelphia, 2013), 8.

19 Madeleine Herren, Hintertüren zur Macht: Internationalismus und modernisierungsorientierte Aussenpolitik in Belgien, der Schweiz und den USA 1865-1914 (Munich, 2000), 129. 
space (within certain limitations): a unique opportunity for members of smaller nations to voice their concerns and concepts, and served as an agent to globalize legal concepts and thus trigger "legal flows." As Mira Siegelberg puts it, "Émigré jurists in Britain and the United States who had turned against international law as a substitute for power politics kept up a fierce campaign to publicize the limitations of the legalist approach to international relations." ${ }^{20}$

"Crimes against humanity" is a term that leans heavily on the keyword "humanity," and links back to Victorian visions of world order, to evoke Duncan Bell's title. ${ }^{21}$ I argue that the selection of "humanity" as the key term within a concept that was a legal tool to punish crimes against civilians formed a bridge between the epistemic communities of the 1870 s and the exiled lawyers of the 1940s, and stressed the idea of a supranational community (like the later UNWCC) as the guardian of justice. The concept of crimes against humanity evinces a universalistic approach to the law, with an emphasis on protecting individuals. Although often perceived as a Nuremberg invention, the concept was not a novelty of the tribunal at Nuremberg, but can be seen as a fulfilment of the so-called Martens Clause of the Hague Peace Conferences and its underlying notion of humanity. ${ }^{22}$

Important for the centrality of the term "humanity" were the two peace conferences at The Hague (1899 and 1907), where a Convention on the Laws and Customs of Warfare was agreed upon. To fill the gap with regard to the legality of certain acts of violence or violent actors, which had not yet been codified, ${ }^{23}$ the Russian representative, Baltic German-born Friedrich (Fyodor) von Martens, suggested the following preamble (which later became known as the Martens Clause). It states, "Until a more complete code of the laws of war is issued ... populations and belligerents remain under the protection and empire of the principles of international law, as they result from the usages established between civilized nations, from the laws of humanity and the requirements of the public conscience." ${ }^{24}$

$20 \quad$ Mira Siegelberg, "Unofficial Men, Efficient Civil Servants: Raphael Lemkin in the History of International Law," Journal of Genocide Research 15/3 (2013), S.297-316, at 304.

${ }^{21}$ Bell, Victorian Visions of Global Order.

22 Kerstin von Lingen, "Fulfilling the Martens Clause: Debating 'Crimes against Humanity,' 1899-1945," in Fabian Klose and Mirjam Thulin, eds., Humanity: A History of European Concepts in Practice from the 16th Century to the Present (Göttingen, 2016), 187-208.

23 Michael Geyer, "Crimes against Humanity" (Nov. 2011), in Gordon Martel, ed., The Encyclopedia of War, Wiley Online Library, at http://onlinelibrary.wiley.com/ doi/10.1002/9781444338232.wbeow146, accessed June 2016.

24 Martens Clause (1899), quoted on the website of the International Committee of the Red Cross, at www.icrc.org/eng/resources/documents/misc/57jnhy.htm, accessed 6 Jan. 2016. 
Although there are several versions of the clause with different wordings, ${ }^{25}$ the three consistent elements of the clause remain "the law of nations, as it results from the usages established between civilized peoples," "the laws of humanity" and the "dictates of the public conscience." From a legal perspective, the most eminent form of "public conscience" was an international criminal court. Both features were crucial elements for the success of the subsequent concept of crimes against humanity, and show up within the legal debates in London during the Second World War. The first diplomatic document to use the term "crimes against humanity" was a joint Allied declaration of May 1915, issued by the French, British, and Russian governments, which accused the Ottoman Empire "of crimes against humanity and civilization" in acts they perpetrated against the Armenians. ${ }^{26}$ International lawyers assert that the Armenia telegram contained the first appearance of the term "crimes against humanity," 27 although it needs to be observed that the political dimension of the use of the term here is clearly much stronger than any legal aspect.

When war was over, the perceived need to transfer the political will into a reliable legal tool vanished under the demands of realpolitik. During the Paris Peace Conference, an Allied commission addressed the question of "offences against the laws of humanity," and compiled a long list of atrocities committed during the First World War as possible charges. ${ }^{28}$ Although the so-called Versailles list represented a first step in coining a minimum standard in warfare, there was considerable resistance by the US to using the term "crimes against humanity" in the commission's report, and no clear agreement on the punishment of perpetrators. The US representative, Robert Lansing, saw a "subjective definition

25 Theodore Meron, "The Martens Clause: Principles of Humanity and Dictates of Public Conscience," American Journal of International Law 94 (2000), 78-89, at 79; Emily Crawford, "The Modern Relevance of the Martens Clause," ISIL Yearbook of International Humanitarian and Refugee Law 6 (2006), 1-18.

26 Daniel Marc Segesser, "On the Road to Total Retribution? The International Debate on the Punishment of War Crimes, 1872-1945," in Roger Chickering, Stig Förster, and Bernd Greiner, eds., A World at Total War: Global Conflict and the Politics of Destruction, 19371945 (Cambridge, 2005), 355-74, at 359; Peter Holquist, "The Origins of 'Crimes against Humanity': The Russian Empire, International Law and the 1915 Note on the Armenian Genocide," unpublished manuscript, passed to me by the author, 30; Michelle Tusan, "'Crimes against Humanity': Human Rights, the British Empire and the Origins of the Response to the Armenian Genocide," American Historical Review 119/1 (2014), 47-77, at 51.

27 M. Cherif Bassiouni, Crimes against Humanity: Historical Evolution and Contemporary Application (Cambridge, MA, 2011), 62.

28 Geyer, "Crimes against Humanity." 
of the dictates of humanity." 29 As a consequence, the term "crimes against humanity" was not mentioned, although all other delegates had agreed in principle. ${ }^{30}$ As Dirk Moses underlines, this can be perceived as a diplomatic rather than an intellectual conjuncture, and implementation was blocked due to an unsatisfactory victory of American conservatism. ${ }^{31}$ As will be scrutinized below, the term "humanity" then surfaced again in UNWCC meetings in 1944 and was taken up by the London Charter for the Nuremberg International Tribunal in 1945 .

\section{DEBATING GLOBAL JUSTICE DURING THE SECOND WORLD WAR}

The engagement of exiled lawyers within the UNWCC and its forerunners was decisive for the finalizing of a century-long debate. The main protagonists presented in this article are the Czech delegate Bohuslav Ecer ${ }^{32}$ and the Belgian representative Marcel De Baer. The unprecedented scale of the Nazi war of aggression formed the basis for growing concern amongst the governments of nine European states that were forced into exile in London, ${ }^{33}$ and the call was made to establish a guideline for trials after the end of the conflict. ${ }^{34}$ As highlighted before, when examining "globality" in terms of scale and public sphere, I propose here to speak of a "London hub," which stresses the institutional connections in London and distinguishes it from the idea of a "London moment." 35 The notion of global moments was introduced first by Erez Manela, ${ }^{36}$ and took in view the anticolonial moment after 1919, and was then taken up by Conrad and

29 Robert Lansing, "Notes on World Sovereignty," American Journal of International Law 15/1 (1921), 13-27, at 25.

30 Van Schaack, "The Definition of Crimes against Humanity," 797.

31 A. Dirk Moses, The Problems of Genocide (Cambridge, forthcoming).

32 The correct Czech spelling of his name would be Ečer. As he signed his name Ecer in London, sometimes even Ećer, the truncated Anglicized version is maintained here for coherence.

33 The nine countries were Belgium, Czechoslovakia, France, Greece, the Netherlands, Luxembourg, Norway, Poland, and Yugoslavia.

34 Arieh J. Kochavi, Prelude to Nuremberg: Allied War Crimes Policy and the Question of Punishment (Chapel Hill, 1998), 3; Kirsten Sellars, Crimes against Peace and International Law (Cambridge, 2013), 60.

35 "The London Moment" is a research project on the governments in exile in London conducted by Julia Eichenberg, Humboldt University Berlin, and the title of her forthcoming book. See https://exilegov.hypotheses.org.

36 Erez Manela, The Wilsonian Moment: Self-Determination and the International Origins of Anticolonial Nationalism (Oxford, 2007). 
Sachsenmeier with a view to global visions of world order. ${ }^{37}$ In global intellectual historiography, Moyn and Sartori speak of a "threshold moment" to describe the "possible formation of an intellectual history extending across geographical parameters far larger than usual." 38 "Hub" seems, however, a more appropriate term for the lawyers' institutional entanglement in London.

In London in the early 1940s, legal circles consisting of exiled lawyers of smaller Allied nations had already started debates on ways to approach crimes committed in the ongoing war: an epistemic community of lawyers, which I perceive as agents of a new, supranational policy. ${ }^{39}$ Most of them were already prominent lawyers in their home countries but forced into exile by Nazi politics. ${ }^{40}$ Especially the Czech and Polish exiled government representatives - with their sentiments echoed by their Belgian and Dutch counterparts-hoped that by establishing fierce legal guidelines the Nazis would be deterred from committing further crimes. ${ }^{41}$

Since they first convened in 1941, the legal circles advocated new ideas of postwar justice within the two forerunners of UNWCC, the International Commission for Penal Reconstruction and Development, emanating from the Faculty of Law at the University of Cambridge (hereafter the Cambridge Commission), and the London International Assembly (LIA). The legal scholar Hersch Lauterpacht, himself an earlier émigré from Lemberg (Lviv) in the former Austro-Hungarian Empire, was particularly active in fostering the debate and hosted the first meetings. Two topics were discussed: first, the definition of war crimes with particular consideration of new crimes, and second, the prospects for establishing an international court. For both topics, the notion of "public conscience," as laid down in the Martens Clause, was key.

To highlight arenas of debate and codification, one needs to look at the context. The first declaration by the nine exiled countries at St James's Palace in January 1942 was surely a moment where the agenda was set by the "semi-peripheral"

37 Sebastian Conrad and Dominic Sachsenmaier, eds., Competing Visions of World Order (New York, 2007).

38 Moyn and Sartori, "Approaches to Global Intellectual History," 4.

39 Kerstin von Lingen, "Setting the Path for UNWCC: The Representation of European Exile Governments on the London International Assembly and the Commission for Penal Reconstruction and Development, 1941-1944," International Criminal Law Forum 25/1 (2014), 45-76, at 46.

40 Papers of the International Commission for Penal Reconstruction and Development, member list, The National Archives, London (henceforth TNA), LCO 2/2973. Of sixteen members of exile countries, five were former ministers of justice, five were high court judges, two were law professors, and the others were their assistants.

$41 \quad$ Lingen, "Setting the Path," 50. 
actors, ${ }^{42}$ while their British hosts and US allies did not yet have a clear idea about how to punish war crimes. This declaration was important in several ways, as it was the first-albeit small_official recognition of the exiled governments' political concerns in London, although the British and US representatives stuck strictly to their neutrality as "observers." 43 The Chinese representative, on the other hand, who also attended the meeting as an observer, clearly had a national agenda, as China was also under occupation by Japanese forces and thus in some ways shared common ground with the community of European exile countries. ${ }^{44}$ Although China at that time was still largely perceived as one of the four "big" Allies, ${ }^{45}$ the subsequent decline of this status was already beginning to be apparent. There can be no doubt that the British and the USA viewed Chinese demands as a deadlock and as pressure to act. ${ }^{46}$ Responding to the Chinese, and subsequent Czech, demands would have meant a much larger commitment of the Allies to war crimes policy than they were ready to provide.

On 14 November 1941, the exiled lawyers met at a conference in Cambridge on Rules and Procedures to Govern the Case of Crimes against International Public Order. Although this commission saw itself as a body of legal scholars, and therefore chose the form of an academic conference to discuss its ideas, ${ }^{47}$ its political implications were clear, as was their affiliation with semi-peripheral states-following my earlier definition of sidelined actors. The exiled lawyers from Belgium, Czechoslovakia, France, Greece, the Netherlands, Luxembourg, Norway, Poland, and Yugoslavia were crucial to the war crimes debate, but relatively powerless to affect outcomes. ${ }^{48}$ The hosting scholars-for example, British law experts Lauterpacht and Professor Goodhart-took the role as moderators who spoke on behalf of US legal theory.

The main questions discussed at the Cambridge Commission were legal obstacles to judging Axis criminality, and the question whether an international or national court should call for justice. ${ }^{49}$ It is noteworthy that the term "war crimes" was not used, but the commission spoke instead of "crimes against the

42 Kochavi, Prelude, 18; A text of the St. James Declaration can be found at "Inter-Allied Conference, January 13, 1942," Bulletin of International News 19 (1942), 52.

43 Kochavi, Prelude, 14.

44 Ibid., 55; on China's general attitude at St. James see Wen-Wei Lai, "China, the Chinese Representative and the Use of International Law to Counter Japanese Acts of Aggression," International Criminal Law Forum 25/1 (2014), 111-32, at 111.

45 Rana Mitter, Forgotten Ally: China's World War II, 1937-1945 (Boston, 2013).

46 Kochavi, Prelude, 55.

47 Segesser, "On the Road to Total Retribution?", 371.

48 Kochavi, Prelude, 23, with special reference to the Czech position.

49 For a summary see United Nations War Crimes Commission, History of the United Nations War Crimes Commission and the Development of the Laws of War (London 1948), 94-9. 
international public order," to cover also crimes against civilians. ${ }^{50}$ As a kind of summary to the work of the commission, Lauterpacht issued a fifty-twopage memorandum on "Punishment of War Crimes," which discussed possible options to circumvent the current legal problems. ${ }^{51}$ In this memorandum, he argued in favor of an international criminal court, if impartiality within the framework of municipal law could be guaranteed. He composed the first new definition to describe crimes against civilians, but did not, however, mention the term "crimes against humanity":

War Crimes may properly be defined as such offences against the law of war as are criminal in the ordinary and accepted sense of fundamental rules of warfare and of general principles of criminal law by reason of their heinousness, their brutality, their ruthless disregard of the sanctity of human life and personality, or their wanton interference with rights of property unrelated to reasonably conceived requirements of military necessity.52

The second pioneering body to precede the UNWCC, the London International Assembly (LIA), was founded in the fall of 1941, on the initiative of the British Peace Movement, the League of Nations Union (LNU) under Lord Robert Cecil of Chelwood.53 This is an interesting approach from the margins, in that a nongovernmental organization took the lead in providing a platform for debate. Legal scholars were sent from Belgium, Brazil, China, Czechoslovakia, France, Great Britain, Greece, the Netherlands, India, Luxembourg, Norway, Poland, the United States and Yugoslavia, and expertise was also welcomed from expelled judges of Jewish descent from Germany and Austria, who had also emigrated to London. ${ }^{54}$ In contrast to the Cambridge Commission, the number of members increased, leading to a partial abandonment of Eurocentrism through the involvement of non-European members demonstrating the potentially global approach and political implications of this legal endeavor. In this regard, the LIA can be seen as a blueprint for the later UNWCC.

The LIA's chairman, the Belgian judge Marcel De Baer, framed several key questions for the debate, concerning the problems of codifying international

50 See proceedings in TNA, LCO 2/2973.

51 Papers of the International Commission for Penal Reconstruction and Development, memorandum Prof. Hersch Lauterpacht (1942), TNA, LCO 2/2973.

52 Lauterpacht memorandum, in The United Nations War Crimes Commission: History of the United Nations War Crimes Commission and the Development of the Laws of War (London, 1948), 95 .

53 The papers of the LNU are kept at the LSE in London. Its catalogue states, "The League of Nations Union (LNU) was formed by the merger of the League of Free Nations Association and the League of Nations Society, two groups working for the establishment of a new world order based upon the ideals of the League of Nations."

54 Dr. Friedburg, expelled by the Nazis from Berlin, was especially active. 
criminal-law and trial procedures. ${ }^{55}$ In a meeting of the LIA of September 1942, De Baer summarized the motivation of the exiled lawyers to engage with coining new law as follows:

This War calls for retribution. The Germans and Japanese and the other Axis partners must be punished for what they have done to us. At the end of the last war, the effect of victory was lost because the aggression remained unpunished: Germany was not made to suffer, and the individual criminals were not punished. This must not be allowed to happen again. It must be brought to the knowledge of future generations that, with each war, the aggressor will be made to suffer more severely and that it does not pay to attack other nations..$^{56}$

The use of the term "retribution" in this statement, which had so far only appeared in propagandistic messages directed to oppressed peoples at home, is particularly noteworthy. "Retribution" has a slightly different connotation in French (pointing at "bringing to court") than it holds in English, and thus the use of this term hints at the problem of language used in the meetings of the various committees, and thereby to the problem of translating concepts. Most of the lawyers were not familiar with English when they arrived in London, and the first debates were actually held in French (as the proceedings of the Cambridge meetings show), and some even in German. There was mutual help between the exiled lawyers to frame the memoranda, as we know from a letter of Ecer, who praised the help and language skills of De Baer, who even had an office in the building used by the Belgian exiled government that he shared occasionally. ${ }^{57}$ The exiled lawyers were polyglot scholars, following the tradition of multilingual empires like the Austro-Hungarian; Ecer, for example, spoke seven languages, but English was not amongst them when he arrived in London.

It was also chairman De Baer who, in December 1943, was sent as an envoy to New York to campaign for the necessity of an international court to punish Axis criminality. ${ }^{58}$ Here, the engagement of the UNWCC crossed lines with that of the World Jewish Congress (WJC), who were lobbying for a "world court" and "new justice" too.59 The alliance of the exiled lawyers from the London

55 London International Assembly, Reports on Punishment of War Crimes, proposal of M. De Baer, "Suggestions for the Scope of Work for the Commission, Provisional Plan of Work," April 1942, TNA, TS 26/873.

56 Proceedings of the 12th meeting of the LIA, 28 Sept. 1942, LSE, LNU 6/5 (thanks to William Schabas for this source).

57 Ecer, Report No 14, 2 April 1944, National Archive Prague, ÚD NAD 615.

58 Sellars, Crimes against Peace, 53.

59 On this part of war crimes trials policy see Mark Lewis, The Birth of New Justice: The Internationalization of Crimes and Punishment, 1919-1950 (Oxford 2014), 158. See also Annette Weinke, Gewalt, Geschichte, Gerechtigkeit: Transnationale Debatten über deutsche Staatsverbrechen im 20. Jahrhundert (Göttingen 2016), esp. 120-30. 
hub with Jewish organizations must be seen as a careful strategic decision and underlines the global approach. However, globality did not blur the lines of their agenda. While the exiled lawyers were aiming at a global settlement of the punishment of crimes against civilians, the Jewish envoys were more concerned with stressing the uniqueness of the Holocaust and its Jewish victims. De Baer met with members of the WJC in London on 27 March 1944. WJC secretary Easterman pointed out, "The Nazi conspiracy against the Jews was a crime of a special and unique character." De Baer rejected this exclusivist argument, and advocated a universalist legal approach, to tackle future crimes against civilians in any circumstances. ${ }^{60}$

Epistemic communities are defined by a shared understanding of terms. Thus it was crucial to define crimes against civilians, as well as war crimes. Contrary to the valid line of legal theory, which maintained until 1939 that war crimes could only involve cases committed within a state's own territory or against its nationals, ${ }^{61} \mathrm{De}$ Baer offered a new line in 1942. In his definition, war crimes could-in a wider sense-be seen as "offences against the ius gentium, or against international agreements (such as The Hague and Geneva Conventions)." "In this situation, the universalism of the Martens Clause and its references to "humanity," "public conscience," and "law of nations as established between civilized peoples" helped to provide a new definition, which would embrace crimes against civilians as well as underlining its global significance. As the court judgment framed it later in 1948, the Martens Clause served as a "legal yardstick." 3

\section{THE UNITED NATIONS WAR CRIMES COMMISSION}

The most important arena of codification for international law was the UNWCC. It was officially founded in London, on 20 October 1943, and began functioning in early 1944. Its objectives were framed for primarily three spheres: the investigation of facts and evidence regarding war crimes, the enforcement of law with respect to the punishment of war criminals, and legal opinions relating to war crimes and the penal liability of perpetrators. ${ }^{64}$

As an organization, the UNWCC was composed of three committees, of which the Legal Committee in London gave the most important input toward

$60 \quad$ For more details see Marie-Anne Weisers, "Juger les crimes contre les Juifs: Des Allemands devant les tribuneaux belges, 1941-1951" (unpublished Ph.D thesis, Brussels, 2014), 83.

${ }_{61}$ Arieh J. Kochavi, "Britain and the Establishment of the UNWCC," English Historical Review 107/423 (1992), 323-49, at 325.

62 TNA, TS 26/873, LIA, De Baer proposal, April 1942.

63 Krupp case (1948), cited after Meron, "The Martens Clause," 80.

64 United Nations War Crimes Commission, 169. 
the development of contemporary international law. Its agenda was, however, contested. The UNWCC chairman, Sir Cecil Hurst, specified in May 1944 in a letter to British Foreign Secretary Anthony Eden that a number of crimes fell outside the hitherto accepted definitions, as they had been committed on racial, religious, or political grounds in enemy territory, and a renewed approach was needed to consider such crimes. ${ }^{65}$ The Lord Chancellor, Viscount Simon, was, however, rather discouraging in his response, warning the UNWCC that its task was limited only to observing and advising and did not include the coining of new law, even more so as the official British position was still to be agreed upon. Exiled lawyers were not entitled to set the agenda for the big allies, was precisely his message.

Regardless, the exiled lawyers were unwilling to stop short of victory. With the continued strength and support of its members, the UNWCC went beyond its mandate and pushed for a real war crimes policy. ${ }^{66}$ The legal committee, under Bohuslav Ecer and Egon Schwelb, spearheaded the debate. Ecer had submitted a proposal to the UNWCC on 27 April 1944, dealing with the problem of aggressive war and advocating the use of the new charge "crimes against humanity" in an international criminal court. However, the British UNWCC representative Arnold McNair rejected this proposal as too far-reaching, and the issue was back to the table for further debate. ${ }^{67} \mathrm{McNair}$-following his earlier criticism as chair of the Cambridge Commission-was especially against Ecer's idea of holding heads of states accountable and applying what he saw as retroactive law. Ecer, in return, felt that it was unacceptable that those who had broken the law so many times should go unpunished simply because established national codes were not sufficient to deal with them. He held the position that the expansive nature of the Second World War had created a new situation, to which new legal responses had to be formulated. ${ }^{68}$ Ecer wrote, "Preparation and launching of the present war must be punished as a crime against peace," and "if there are gaps in law, it is our duty to fill them." 69

In Ecer's memorandum submitted to the UNWCC in May 1944, the Czech delegate amended his earlier report, following a twofold argumentation. ${ }^{70}$ First,

65 Cited after the Schwelb report on the definition of crimes against humanity, 22 March 1946, PURL, at www.legal-tools.org/doc/c52df5, 3 .

66 Sellars, Crimes against Peace, 58.

67 Ibid., 58-64.

68 Ibid., 61.

69 UNWCC, minutes of 36th meeting, 17 Oct. 1944, TNA, FO 371/39005; see also Sellars, Crimes against Peace, 63, on the connection with Russian legal scholar Aron Trainin.

70 Ecer, Additional Note, 12 May 1944, UNWCC III/4, "Scope of the Retributive Action of the United Nations According to Their Official Declarations: The Problem of War Crimes in Connection with the Second World War," PURL, at www.legal-tools.org/doc/6335bd. 
he suggested broadening the entire concept of war crimes, and second, he advocated the use of the term "crimes against humanity" by drawing on its prior use in international criminal law. In assessing the historical record of Nazi crimes, Ecer stated that the UNWCC had received several accounts of the planned nature of Nazi warfare especially in Eastern Europe, where not only Jews, but also other civilians, were slaughtered by SS troops without prior trial. ${ }^{71} \mathrm{He}$ proposed the new term "crimes against humanity" to cover these offences. By debating the Martens Clause and the Versailles achievements, Ecer stressed the fact that the Preamble of the Hague Convention - the Martens Clause-was of immense value for the work of the UNWCC, as it referred to the term "humanity." 72 In this regard, Ecer was later backed by Schwelb. ${ }^{73}$ Ecer concluded that, in his view, crimes against humanity were the most important concept of all, as they had been committed "as the real cause of all the other crimes, as the source of the war, the malum in se."74 Ecer recalled in his memoirs his deep personal commitment: "The atmosphere was tense, as in my opinion we discussed the whole rationale of the war in light of international law, that must necessarily lead to the victory of justice over the dark forces of evil and bring its perpetrators to the justice they deserve."75

US representative Herbert Pell also supported the new term, and used it in a letter to Roosevelt. ${ }^{76}$ In March 1944, he had summarized the understanding of this concept as it had been discussed among the members of the UNWCC. ${ }^{77}$ It seems that the whole debate on crimes against humanity focused heavily on the Holocaust crimes, which until then had been dealt with among the bulk of Nazi occupation crimes-an act that minimized their distinctiveness. But as Ecer's biography shows, he was equally concerned with crimes against political opponents, as he himself had been imprisoned by the Gestapo as a socialist party delegate. ${ }^{78}$ While Ecer's proposal was again met with criticism, this time it was supported strongly by the British Australian Lord Wright, as well as the Chinese

Ibid., at 2.

Ibid., at 4 .

"Material for the Preparation of a Definition of 'Crimes against Humanity'," compiled by Egon Schwelb, III/33, 22 March 1946, PURL, at www.legal-tools.org/doc/c52df5, 1.

74 Ecer, Additional Note, 12 May 1944, 7.

75 For biographical sketch of Ecer see www.valka.cz/clanek_12304.html, accessed 16 Aug. 2013. Thanks to Katarina Morozova for translation.

76 Pells UNWCC note of 18 March 1944, PURL, at www.legal-tools.org/doc/2aa8b6.

77 Graham Cox, "Herbert C. Pell, US Representative on the United Nations War Crimes Commission," in J. Simon Rofe and Andrew Stewart, eds., Diplomats at War: The American Experience (Dordrecht, 2013), 151-69, at 155.

78 Biographical sketch of Ecer. 
delegate Wunsz King, ${ }^{79}$ and finally it was successful in convincing the other UNWCC members. For Ecer it was a personal victory when "crimes against humanity" was formally laid down in the London Charter on 8 August 1945, although he had no chance to take part in the meetings.

When assessing the records of the lawyers involved, another aspect of "legal flows" attracts attention: the origin of many of the lawyers from the multiethnic and multilingual Austro-Hungarian Empire, where Vienna, Prague, and Lemberg (Lviv) formed hubs of legal scholarship. Ecer and Schwelb had both studied at Prague and Vienna, as Polish lawyer Stefan Glaser had in Vienna and Lviv. It is plausible that they all were already acquainted with scholars like Lauterpacht or Raphael Lemkin, the father of the concept of genocide-both having once studied at the University of Lemberg and Vienna-although the UNWCC sources do not reveal this connection. In assessing their background, I argue that the noteworthy element which proved decisive was not so much the regional affiliation and Central European background, ${ }^{80}$ as it was the early experience of violence and anti-Semitism in a university town on the margins of the fading Habsburg Empire. They were deeply affected by personal experience of persecution and aimed to find a legal solution to bring the criminals to trial. ${ }^{81}$ In this regard, violence formed the link also with the Chinese delegate and his experience of Japanese occupation.

The exiled lawyer's engagement is characterized by strong personal commitment, almost a "mission" to advance the law with all their energy (Raphael Lemkin surely being the best-known example of tireless campaigning for his new term "genocide," 82 although he had no ties with the UNWCC or other committees).$^{83}$ It was one of the flaws of legal debate that the concepts of crimes against humanity and genocide developed into two concurring tools, although

79 Bohuslav Ecer, Vývoj a základem mezinárodního trestního práva (Development of International Criminal Law) (Prague, 1948), 122. Thanks to Petra Krupičková for translation.

8o Although I agree with Philippe Sands, East West Street: On the Origins of "Genocide" and "Crimes against Humanity" (London, 2016), that this was a forming factor, I think it was more for its historical context and personal experiences with violence.

$81 \quad$ Lingen, "Setting the Path," 45.

82 Weinke, Gewalt, Geschichte, Gerechtigkeit, 119-25; Daniel Marc Segesser and Myriam Gessler, "Raphael Lemkin and the International Debate on the Punishment of War Crimes (1919-1948)," Journal of Genocide Research 7/4 (2005), 453-68.

83 Siegelberg, "Unofficial Men," 309: “Though Lemkin's ultimate goal was the creation of a law that made genocide a crime, his method for creating international law was decidedly and self-consciously outside the realm of committee meetings, codification and expert analysis." 
Schwelb had argued earlier that they initially formed "two rivers flowing under two different names," and needed to be united after the war. ${ }^{84}$

The legal actors were also serving as intellectual intermediaries in the most specific sense. Upon reviewing the minutes, it becomes clear that the absence of the Soviet Union from the UNWCC meetings, as well as the apparent friction between Stalin and the British government, was a major concern. ${ }^{85}$ While the war raged on, the Soviet Union was seen as an important ally of the Central and Eastern European states. ${ }^{86}$ Czech and Polish delegates were in constant exchange with Soviet scholars, and men like Czech president Edward Beneš never hid the fact that the smaller states were in search of justice and support and willing to accept help from Stalin if Washington and London hesitated. ${ }^{87}$ This attitude was strengthened by the fact that scholars like Lauterpacht, Ecer, and Schwelb could read Russian and were attracted by some new legal theories.

Western scholarship has often overlooked the fact that Soviet law scholars were among the first to advocate criminal proceedings against the Nazi elite. ${ }^{88}$ Aron Trainin's theoretical work on the prosecution of war criminals involved the concept of conspiracy, the credit for which was later attributed exclusively to the US prosecution at Nuremberg. ${ }^{89}$ Trainin's research was disseminated during the war, already translated into English before the Moscow Conference in October 1943 , as if Stalin wanted to test his position on his Western counterparts. Following the Moscow Conference, the Soviet Union held a first trial in Kharkov..$^{90}$ Ecer was among the scholars who were attentive to the Soviet message emanating from the trial that justice for war crimes was on the top of the agenda for Soviet policy. ${ }^{91}$

84 Letter of Schwelb to Humphrey, 7 June 1947, UNOG library, cited in Siegelberg, "Unofficial Men," 304.

85 Vit Smetana, "British and U.S. Perceptions of Edvard Beneš and His Foreign Policy in the Last Ten Years of his Life," in Ota Konrad and René Küpper, eds., Edvard Beneš: Vorbild und Feindbild. Politische, historiographische und mediale Deutungen (Göttingen, 2013), 127-52, at 141.

86 Holquist, "Crimes against Humanity."

87 Note of meeting with General De Baer, by Wright, 1 Dec. 1944, National Archives of Australia (henceforth NAA), A 2937/273, 2.

88 A noteworthy exception is Francine Hirsch, "The Soviets at Nuremberg: International Law, Propaganda, and the Making of the Postwar Order," American Historical Review 113/3 (2008), 701-30. New research is given by Valentyna Polunina, "The Human Face of Soviet Justice? Aron Trainin and the Origins of the Soviet Doctrine of International Criminal Law," in David Crowe, ed., Soviet Contribution to International Law (forthcoming 2018).

89 Hirsch, "The Soviets at Nuremberg."

90 On Soviet trial policy see an overview by Tanja Penter, "Local Collaborators on Trial: Soviet War Crimes Trials under Stalin (1943-1953)," Cahiers du monde russe 49/2-3 (2008), 341-64.

91 Sellars, Crimes against Peace, 53. 
In his booklet The Lessons of the Kharkov Trial, Ecer praised the proceedings conducted against three German officers and one local collaborator as a model for future war crimes trials. ${ }^{92}$

The Central European lawyers felt sometimes betrayed by their British hosts. Ecer had been approached by the Soviets already in October, but the UNWCC chair, Cecil Hurst, had not passed the information on to other members, silencing the offer instead. ${ }^{93}$ Ecer had highlighted that the Soviets wanted a cooperation with the UNWCC if, as well as the British dominions Australia, Canada, New Zealand, India and South Africa, Soviet satellites like Ukraine, Belorus, Estonia, Latvia, Lithuania, and Finno-Karelia would have a voice. ${ }^{94}$ This was politically unacceptable for the US and the British position, and thus the proposal was shelved. This led the Central European lawyers to consider quitting the UNWCC, and turning to the Soviet war crimes commission, perceived as more progressive. De Baer told Lord Wright confidentially about these plans: "De Baer said he ... had heard Ecer and Zivkovic express sentiments that they would prefer to remain on the Commission in London, but if things went on as at present they would certainly turn to the strong Russian Commission." 95

The British government was still reluctant to respond to the new term. In a debate in the House of Commons on 4 October 1944, referring to the killings of political prisoners in the Buchenwald concentration camp, Foreign Secretary Eden stated, "Crimes committed by Germans against Germans, however reprehensible, are in a different category from war crimes and cannot be dealt with under the same procedure." 96 This notion was reaffirmed in a debate on 31 January $1945 .{ }^{97}$ It was still some way to go to include the concept of crimes against humanity into international law. The time came when war was over, and the first international tribunal had to be set up. The first legal document using the concept of crimes against humanity was the charter for the International Military Tribunal to be held at Nuremberg, agreed upon at a conference in London on 8

92 Bohuslav Ecer (under the pseudonym B. Etcher), The Lessons of the Kharkov Trial (London, 1944).

93 Proposal by Dr. Ecer, "THE USSR and the Problem of War Crime: The Conception, Punishment and Prevention of War Crimes According to the Soviet Doctrine of International and Criminal Law," text of a lecture delivered under the auspices of the Society for Cultural Relations with the USSR on 14 December 1944, NAA Canberra A2937/274, 176-91.

94 Letter of Ecer to Hurst, 5 Oct. 1944, NAA, A 2937/273.

95 Note of meeting with General De Baer, by Wright, 1 Dec. 1944, NAA, A 2937/273, 2.

96 Cited after Schwelb report on the definition of Crimes against humanity, 22 March 1946, PURL, at www.legal-tools.org/doc/c52df5, 5 .

$97 \quad$ Ibid. 
August $1945 \cdot{ }^{98}$ A first legal definition of the term "crimes against humanity" was included in Article 6(c) of the Nuremberg Charter. 99

Until today, scholarship on the emergence of the new term has been loaded with mythical undertones, which this article has tried to oppose. ${ }^{100}$ The conventional narrative suggests that US envoy Robert Jackson brought it up at the conference, giving credit to "an eminent scholar of international law." ${ }^{101}$ This hinted at Hersch Lauterpacht, ${ }^{102}$ then a professor at Cambridge who hailed from the former Austro-Hungarian Empire, whom Jackson had consulted only a day earlier. Since then, legal scholars have focused on Lauterpacht's role. ${ }^{103}$ However, the different strands woven together into the concept derived from earlier wartime debates in London, as we have seen.

\section{CONCLUSION}

When assessing the commitment of predecessors to the UNWCC and representatives of smaller Allied states toward the cause of international criminal justice, three points need to be underlined. In the first place, the commitment of smaller Allied states to frame international criminal law with regard to war crimes was crucial. Exiled lawyers and Jewish emigrés alike changed the perception of international law into a protector, as they put more weight on the experience of violence and victim's voices than on the earlier approach of protecting states from violence (for example, the Belgian motion in the Versailles Conference). This stance also mirrors the political situation of the time: the debates stemmed from a perspective of political powerlessness: exiled politicians and experts keenly felt the low position their agendas occupied among their British hosts. To be sure, Lauterpacht's role in developing new law was crucial, as he acted as a transmitter between the voices from the periphery toward the real powerful bodies at the

98 The text of the Nuremberg Charter/London Conference can be found in the Avalon project section of the Yale Law school website at http://avalon.law.yale.edu/imt/jack6o.asp, accessed 6 Jan. 2016.

100 David Luban, "A Theory of Crimes against Humanity," Yale Journal of International Law 29 (2004), 85-167. He states at 86 that "no record exists of how the term crimes against humanity came to be chosen."

101 Robert Jackson, Report on the International Conference on Military Trials at London, 1945 (Washington, DC, 1947), 416.

102 Koskenniemi, Gentle Civilizer, 388-9, on Lauterpacht's decisive role within the British prosecution team.

103 William Schabas, Unimaginable Atrocities: Justice, Politics, and Rights at the War Crimes Tribunals (Oxford, 2012), 51; Elihu Lauterpacht, The Life of Sir Hersch Lauterpacht (Cambridge, 2010), 272; Sands, East West Street, 109-11. 
Allied conference. But the idea did not originate with him, as it is commonly supposed it did.

The second point to be emphasized is that the "London hub," during the first half of the 1940s, created the framework for advancing, within limits, a victim-centered "new justice." Thus the predecessors of the UNWCC served as an epistemic community involving some of the most renowned lawyers of the time, forming a truly transnational intellectual network. The surrounding debates about legal terms are vital to understanding the impact of its work, as is the influence of Soviet voices on these debates, which in the Cold War era became marginalized. Soviet scholars' influence had been especially appealing to the Central European exiled lawyers. With growing disappointment about the slow progress of British and US support and confronted with the experience of double standards at Nuremberg, the Soviet approach became an academic inspiration-if not a political alternative-for legal scholars like Ecer.

Third, the endeavor was global: with the LIA, the Eurocentric perspective opened up at least partly, and East Asian views and legal concerns of the Pacific war were taken into consideration as well. The support of the Chinese delegation for Ecer's proposals was critical in forming a majority in the UNWCC. The UNWCC thus represented an important moment in the broader trajectory of challenging legal Eurocentrism, which was powerfully reinforced by the UN Declarations on Human Rights and on Genocide in 1948. As I have shown, exiled and "semi-peripheral" lawyers played a crucial role in crafting such norms of universal law.

Furthermore, I would assert that the notion of exile itself created a "global moment," and triggered the advent of universalist approaches to law. The exiled lawyers' engagement with, and facilitation of, "legal flows" thus demonstrate the significant intellectual role played by marginalized academic-juridical actors in a difficult political context, in the forging of new globalized legal concepts. 